\title{
Integrated Structure and Specific Solutions for Sustainable Development of Islands' Special Economic Zone: A Practice in Phu- Quoc Island, Vietnam
}

\author{
Đao Mạnh Tien ${ }^{1}$, Pham Van Thanh ${ }^{1}$, Đao Manh Tri ${ }^{1}$, Đang Thị Huong ${ }^{1}$, Đao Huong Giang ${ }^{2}$ \& Pham Thai Nam ${ }^{1}$ \\ ${ }^{1}$ Institute of Natural Resources, Environment and Sustainable Development, Vietnam Union of Science and \\ Technology Associations, Hanoi, Vietnam \\ ${ }^{2}$ National Economics University, Hanoi, Vietnam \\ Correspondence: Pham Thai Nam, Institute of Natural Resources, Environment and Sustainable Development, 114 \\ Tran Huy Hung Str., Hanoi, Vietnam. Tel: 84-243-784-2548. E-mail: phamthainam@yahoo.com
}

Received: July 22, 2020

doi:10.5539/jsd.v13n5p31
Accepted: September 11, 2020

Online Published: September 28, 2020

URL: https://doi.org/10.5539/jsd.v13n5p31

\begin{abstract}
A success achievement for Sustainable Development Goals (SDGs) requires four key elements: Suitable Sustainable Development (SD) model; Feasible policies; Mobilizing resources; and Consensus of the people. Establishment of a simple, common, easy-to-use process or an approach to the building of an SD model would be key importance. This could make it easier for countries or small regions where expertise resource is limited.

This paper addresses two main objectives: 1) demonstrate the importance of systematic analyses and the creation of a Practical SD Structure (PSDS) at the first stage of an SD study; and 2) perform complete research at a selected pilot area, using it as the practical basis to establish component models for individual aspects of SD.

This work selects Phu Quoc Special Economic Zone as a case study. It approaches three strategic goals for SD to build a comprehensive process from setting up a procedure for the creation of a visualized PSDS, identifying targets for SD, challenges, key partners, to ultimately providing analyses and practical solutions for SD issues.

The results demonstrate that while only the SDGs are relatively homogeneous in different study areas, implementing partners may have similarities, so the identification of challenges, priorities, determination of tasks and responsibilities in interactions between partners is highly variable; The SD model for each specific area always requires systematic analysis. It must be based on practical conditions and pursuing feasibility. The results provide practical solutions, directly applicable to the study area. However, the approach of the work and structure of the models allow flexible application for others.
\end{abstract}

Keywords: balance, development, Island, model, Phu Quoc, policy action, special economic zone, structure, sustainable

\section{Introduction}

Since 2015, fifteen areas along the coastline of Vietnam have been identified as the key areas to concentrate investment in economic development. This move is within the broader strategy of the Vietnamese government in coastal socio-economic development. In particular, Phu Quoc Island, with its geographical, natural, economic, and social characteristics, is expected to be one of the bright spots in that strategy.

Regarding economic development strategies in Vietnam, with the view that economic development is a basic element for SD, Nguyen H. S. (2009) introduced the concept and the relationship between economic SD and SD, as well as the impact of economic development on cultural, social, and environmental issues. Le T.K.T. (2016) suggested that the construction of coastal Economic Zones (EZ) is completely consistent with the current development trend of the world as well as the requirements of Vietnam's economic and security development in the new situation. Pham V. T. and Dao M. T. (2018) emphasized that from the experience of coastal EZs and coastal Special Economic Zones (SEZs) development in several countries such as China, India, and South Korea, it has helped draw lessons for Vietnam, and the establishment of a "Scientific basis and solutions for SD of coastal economic zones in Vietnam" is an urgent issue. However, a suitable SD model is likely the key to achieve the goals.

Policy issues for SD in Vietnam have been widely discussed. They are social security and SD (Du V. T., 2013); 
Renewable energy development on the sea and development orientation (Le A. T., 2009); Responding to climate change impacts on ecosystems and rural development (Pham H. H., 2006).

There are a number of studies related to successful SEZ models in the world (UNCTAD, 2019). They especially related to: Coastal economic SD in neighboring countries (O'Connor, 2006); Focuses on the analysis of aspects for SD in the region such as Thailand (Nitivattananon \& Srinonil, 2019), Malaysia (Rabe, Osman, \& Bachok, 2012), Indonesia (Kurniawan \& Managi, 2018), and in Vietnam (Minh D., 2018); Experiences from theory to practice of the development of coastal EZ in Vietnam (UNDP, 2014); Measures to strengthen capacity to implement the national strategy on climate change (Minh H., 2019); Practical models in environmental friendly waste treatment (Ngo V. L., 2013).

The challenges of SD are also frequently discussed in publications, from universal such as for SDGs at a global scale (UN, 2013), and specific regions (Adhikari, 2018), to each aspect of SD including economy, environment (Stephen et al., 2019), policies, and partnerships for SDGs at different scales (Ugochukwu, 2019), as well as challenges for specific activities such as tourism (Tosun, 2001), agriculture (Antle \& Ray, 2020), and sociocultural (Kopnina, 2016).

In general, the studies mentioned above have different approaches in assessing and addressing aspects of SD. However, there is still a gap in making them into application practice.

\subsection{Framework of the Study}

\subsubsection{The Theories}

Many efforts have been made to bring knowledge on SD into management practices. However, it is necessary to interpret the SD concepts into visible and accessible practices, as well as bringing the theoretical models into practical, empirical-based examples. A success achievement for Sustainable Development Goals (SDGs) requires four key elements: suitable SD model; feasible policies; mobilizing resources; and consensus of the people. Establishment of a simple, common, easy-to-use process or an approach to the building of an SD model would be key importance. This could make it easier for countries or small regions where expertise resource is limited.

\subsubsection{Objectives}

This study is to: 1) demonstrate the importance of systematic analyses and the creation of a PSDS at the first stage of an SD study at a specific location. In which, the PSDS could help to recreate a "real-time" image of the SD status of the study area, providing a guideline to keep-in-track the follow-by solutions; 2) perform complete research at a selected pilot area, using it as the practical basis to establish component models for individual aspects of SD.

\subsubsection{The Scope}

This work selects Phu Quoc SEZ as a case study, where common SD issues are briefly discussed.

The study inherits the core SD criteria, looking to build a comprehensive process from setting up a procedure to the building of SD structure, identifying challenges, and ultimately providing analyses, specific solutions for SD issues of the study area.

Establishment of component models to address challenges based on mandatory criteria: Feasibility; Practical applicability; and Open structure that allow adjusting the task once a new challenge appears.

\subsubsection{The Study Outputs}

Throughout the content of this paperwork, three main groups of results will be discussed. They are, respectively: 1) The procedure to create a PSDS; 2) The practical SD structure; and 3) Ten component models consisting of organizing, coordinating, controlling, and policy actions for SD of the study area.

\subsection{Phu Quoc Island}

Phu Quoc SEZ (hereafter referred to as Phu Quoc) belongs to Phu Quoc Island district. It is located in the extreme southwest of Vietnam with a natural area of $589.05 \mathrm{~km}^{2}$ (Figure 1). It is one of the fifteen coastal EZ of Vietnam and was selected to become a concentrate invested SEZ (The Prime Minister, 2013; Phu Quoc, 2020). 


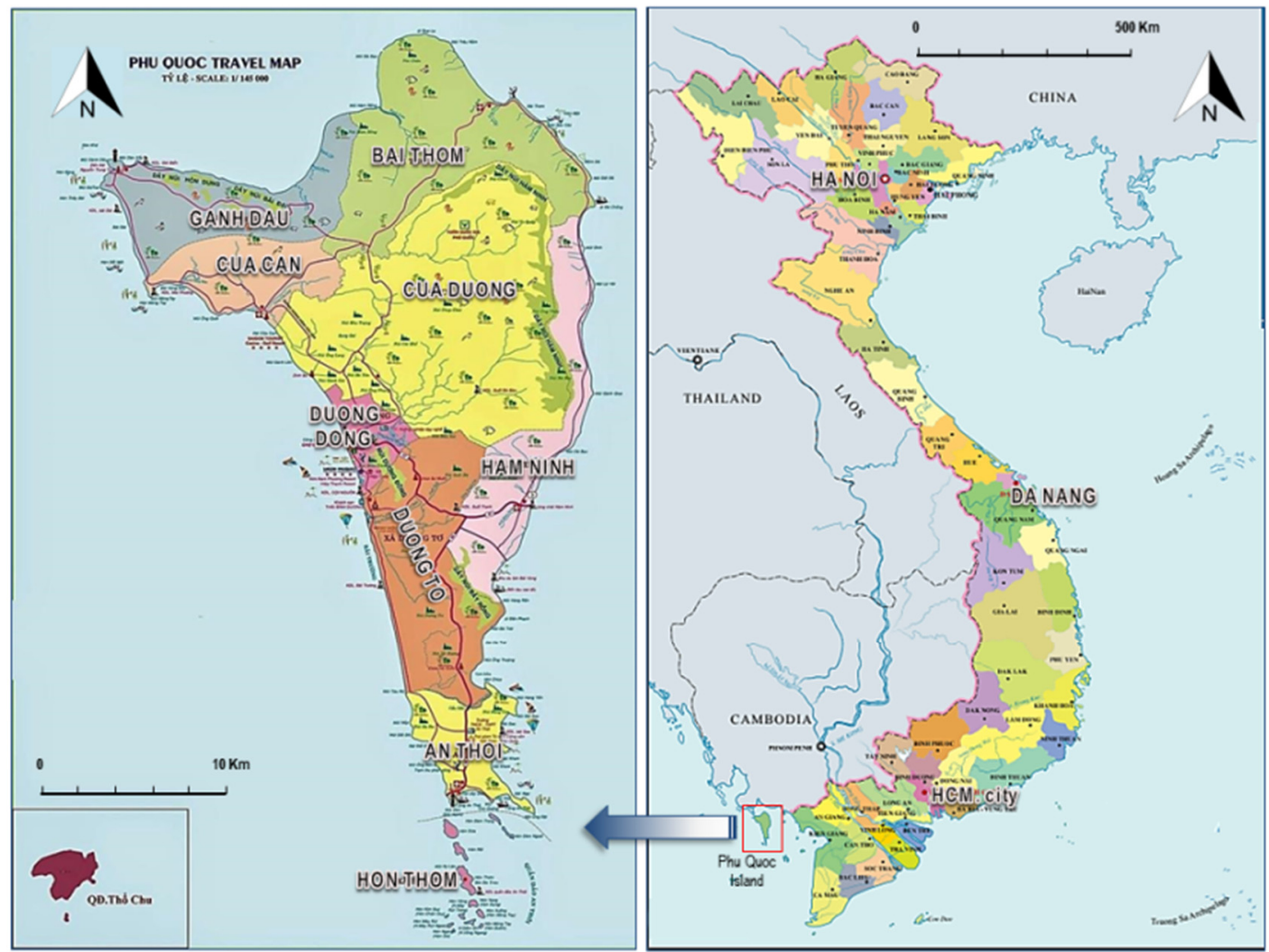

Figure 1. Phu Quoc Island, Vietnam

Phu Quoc has primary rainforests, plantations, melaleuca forests, mangroves, wetlands, coral reefs, and seagrass beds, where there is high biodiversity, containing rare and endemic genetic resources. Phu Quoc's National Park is one of the core areas of Vietnam's largest biosphere reserve (Pham V. T. \& Dao M. T., 2018). The annual average temperature is about $25^{\circ} \mathrm{C}-27^{\circ} \mathrm{C}$, warm throughout the year, and few adverse weather phenomena.

The island's economy has grown at a high rate, with the average annual GDP during the period of $2010-2017$ increasing by $38.5 \%$ per year. Of which, tourism and services contribute $60 \%$ (2017); industry - construction and agriculture - forestry - fishery give addition to $21 \%$ and $19 \%$ respectively (Kien Giang 2018).

Natural resources in the island are currently facing the risk of depletion due to over-exploitation of minerals, shipping, tourism, and so on. This puts pressure on the soil, water, and air environment on the land and the sea, seriously affecting the ecosystem and the lives of residents. Coastal erosion, sediment deposit, and canals changes occur more frequently in estuarine and seaport areas (Dao M. T. \& Pham, V. T., 2007). Without exception, Phu Quoc Island is facing significant challenges on its way towards SDGs.

It is not just the political will at the national or provincial level, people of Phu Quoc also expect in a bright prospect, when the island "gradually became a major tourist - service center of the country, region and international under the SEZ form, extroverted, with three main pillars: Entertainment - Resort industry; Banking - Financial services; And Marine economics" (The Prime Minister, 2004).

\section{Methodology}

\subsection{Principle on SD Models}

Sustainable development is "the development of mankind that not only focuses on economic development but also respects the essential needs of society and the impact on the ecological environment". The goals of sustainable development are to "achieve material adequacy, spiritual and cultural wealth, equality of citizens and consensus of society, harmony between man and nature" (IUCN, 1980). Therefore, the sustainable economic development model must be based on the principles of feasibility, economic efficiency, environmental protection, and climate change adaptation, ensuring welfare. The scale must be in line with the new mechanism in the market economy. The model must be stable, capable of self-regulation, and self-development, limiting emissions and progress to zero-emission. 


\subsection{Criteria for Evaluating the Feasibility}

The proposed models must be assessed for their practical applicability through multi-criteria analysis. The set of evaluation criteria is based on the following factors: 1) Harmony between economic, social and environmental development; 2) Maintaining sustainable economic growth in parallel with progressive implementation, social justice, and environmental protection; And 3) Meet the legal basis as appropriate for planning, location, scale, regional integration policies, and policies to encourage the application of cleaner production.

Most SD viewpoints believe that it must be based on three main pillars of economic sustainability, social sustainability, environmental sustainability. Besides, one more aspect is institutional sustainability. Each pillar and aspect will have a set of indicators to assess their sustainability. The Dow Jones Sustainability World Index first launched in 1999 uses a set of criteria to evaluate SD with three dimensions of economy, environment, and society (Dow Jones, 2012). The Global Reporting Initiative (GRI, 2002) applies a set of criteria that still basically revolved around the three pillars of SD. However, it is more detailed on Economy - Environment - Labor - Human Rights Society - Responsible products. The United Nation's set of criteria is still based on three pillars of economy, society, and environment, but it has mentioned more about institutional areas with two aspects: the institutional framework (two indicators) and institutional capacity (four indicators). However, depending on the conditions and circumstances of each country, concerning the fields and subjects of study, the evaluation criteria will flexibly change accordingly (UN, 2015).

In this study, SDGs according to The 2030 Agenda for Sustainable Development (UN, 2015), integrated with Vietnam's SDGs (MPI, 2019), and taking into account the feasible conditions of Vietnam, are used as a basis for consideration of SDGs for Phu Quoc.

In addition to complying with SDGs, this study focuses more on analysis and construction of: 1) Procedure for the building of an SD model, which describes the principles and procedures for conducting a sustainable development structure in a practical and flexible manner for an SEZ; 2) A Practical, Localized SD Structure (PSDS) for Phu Quoc, which clarify challenges, position, role, and interactions between components of SD; And 3) Solutions distinctively for SD. These solutions are demonstrated through practical models, consisting of organizing, coordinating, controlling, and policy actions. It helps solve the identified challenges and priority issues that exist in an SEZ.

\subsection{The Procedure to Create a PSDS}

In this work, PSDS for Phu Quoc is built in a four-step sequence and is based on a feasibility analysis platform (Figure 2). Starting with (1) identify the basic Targets in SD of the study area; Then (2) identify practical Challenges; And (3) The Key implementation Partners (key players); Next, (4) to determine the Tasks and Responsibilities performed to cope with the challenges to reach the set targets. All four steps above need to be carried out in sequence. However, at each stage, a reference to (5) Feasibility analysis is essential. It ensures the model always in the right direction, updated with reality and respond flexibly to changes in local practical conditions. In other words, feasibility analysis plays a fundamental role, helping to actualize, localize, and up-todate the model.

After the four steps, in the opposite direction, the responsibilities and execution tasks will be Assigned to each or each group of key partners for Addressing a specific challenge that has been identified, thereby Approaching the initiated targets.

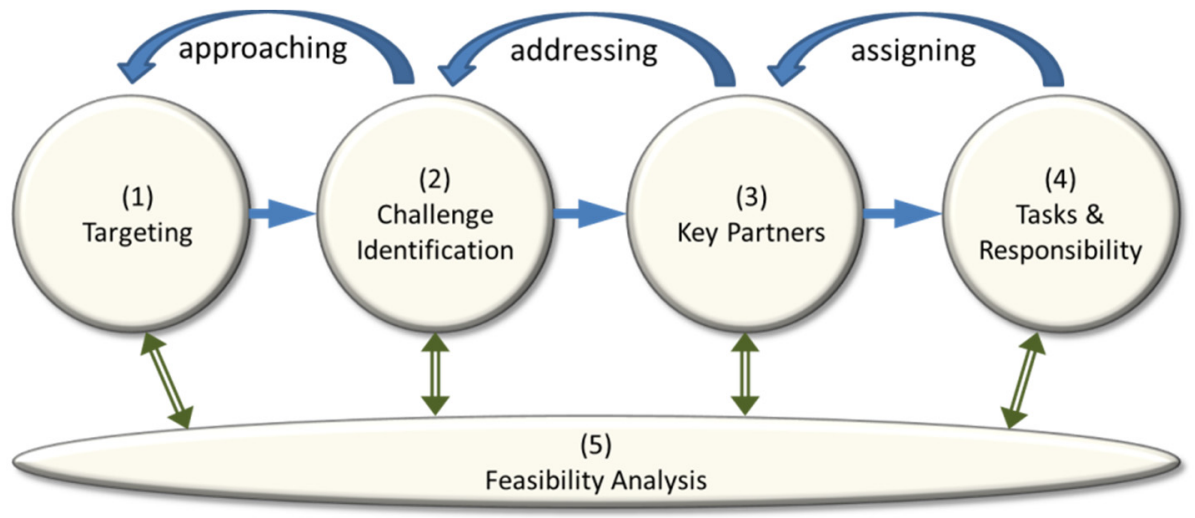

Figure 2. Procedures for building a Practical Sustainable Development Structure (PSDS) 


\section{Results and Discussion}

\subsection{The Practical SD Structure}

Realizing the steps in the Figure 2, the diagrams of three-pillars for SD (Elkington, 1997; Purvis et al., 2018) is employed. The idea of building a house is used to describe the structure and the role of each component (Figure 3). In particular, each pillar for SD (namely Environment, Economic, and Social) corresponds to a core target of the model. They need to be shaped with Bricks"br Blocks"bf Challenges.

This work emphasizes the identification of existing challenges that are believed to directly affect the study area. At present, the number of five most critical challenges for each pillar is selected and sorted by priority (Figure 3).

To make these pillars stand firm, a strong foundation is a must. In this case, each Key Partner is considered as a cornerstone. Tasks and Responsibilities are like the materials that hold them together, filling the gaps between the individual. They together create the perfect foundation for the pillars.

Similar to the construction of a house, from the beginning to the finish, the selection of materials, their size, quantity, or weight should consider the feasibility of the soil ground where the structure is built. In other words, when building it, from the very first step, always keep in mind that the work is for and on its ground of Feasibility.

Generally, the PSDS of Phu Quoc is characterized by actuality of the study area. It approaches three strategic goals for SD, identified fifteen challenges with their levels of current priority to meet the SDGs. It identified four partners acting as key-players, clarified their tasks and responsibilities based on interactions between the parties (Figure 3).

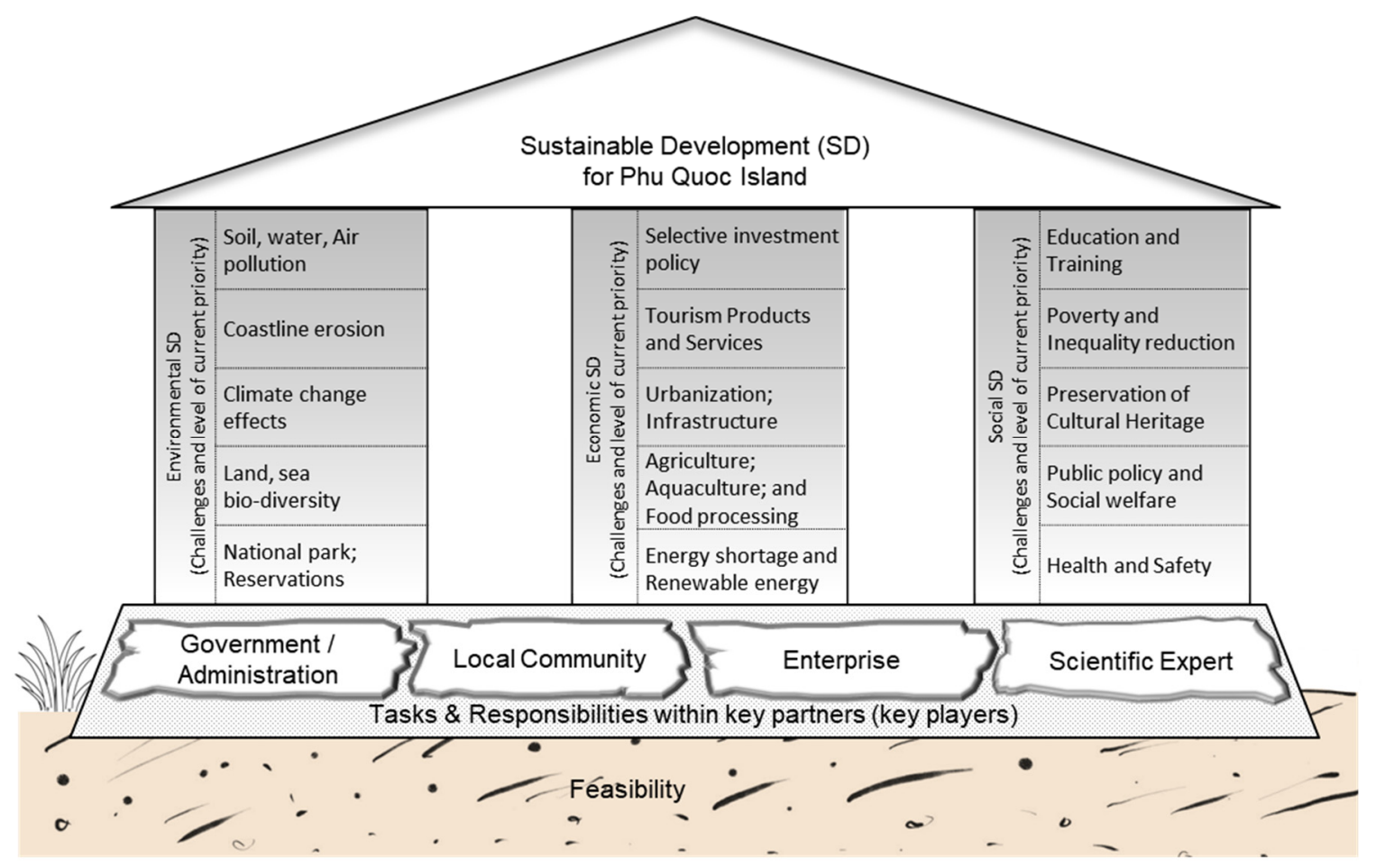

Figure 3. The Practical SD Structure for Phu Quoc

\subsection{Economic SD Models}

Four main economic sectors contribute to the recent high growth of Phu Quoc's economy. They include, in order of high to low, Tourism, Trade - Services, Processing industry, and Agriculture-Forestry-Fishery. However, because economic orientation concentrates on tourism and services - trade, it is necessary to select a category of economic activities that are encouraged to invest. So that, it will 1) take advantage of and maximize the available resources and 2) be able to connect and turn other economic sectors into important chain eyes, be together with tourism and services to create high economic value chains.

Within this paperwork, four detailed models for the economic SD of Phu Quoc are discussed. These include Tourism Value Chain; Tourism Connections; Renewable Energy; and Aqua-Agroforestry. 


\subsubsection{Tourism Value Chain Model}

Sustainable tourism development model of Phu Quoc EZ (Figure 4) is created according to the value chains analysis (OECD / UNWTO / WTO, 2013). In particular, it is based on factors forming tourism products such as superior tourism resources; Enterprises with the role of providing services; Local governments implement mechanisms to manage and invest in tourism development; And residential community with local culture and traditions.

\section{Tourism Resources:}

Natural tourism resources: coral, sea grass, and mangroves ecosystems. Phu Quoc National Park

Cultural tourism resources, history, humanities: Historical relics of Phu Quoc prison; Nguyen Trung Truc, Dinh Cau tempres; Dinh Ba Ong Lang festival, boat racing.

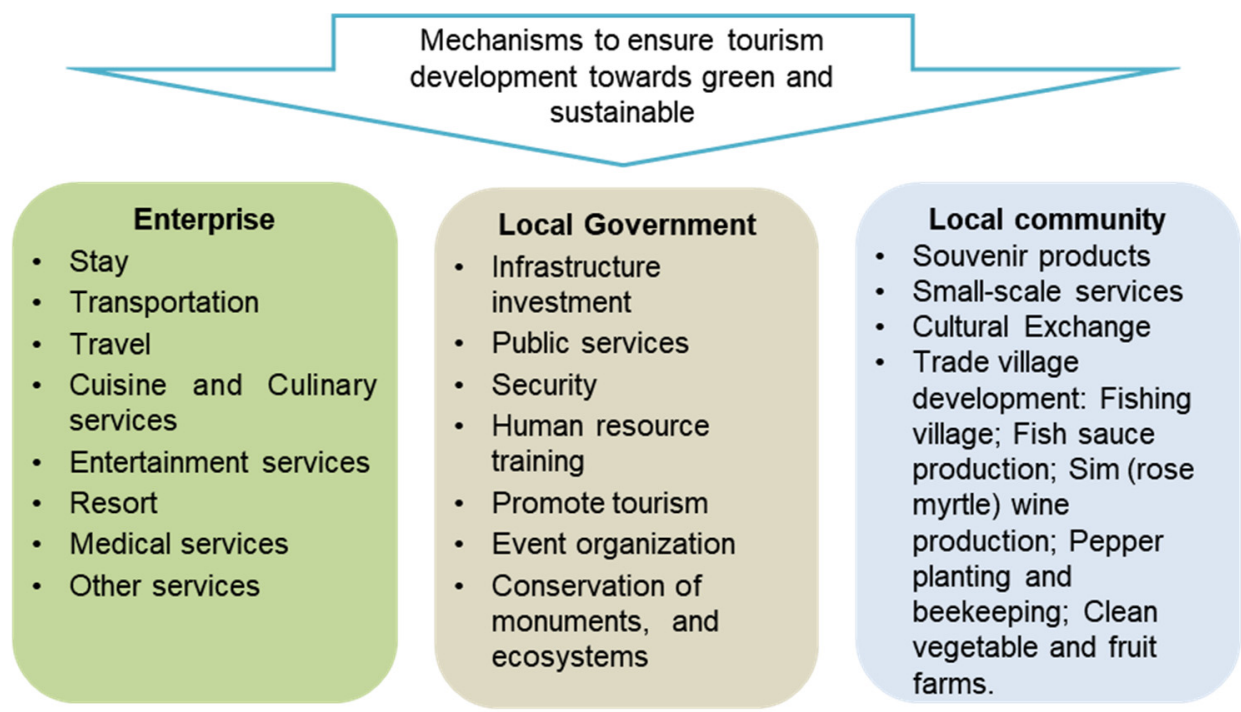

\section{Sustainable Tourism Products}

Ecotourism:

Swimming, diving to discover coral and sea grass; exploring mangroves; Phu Quoc National Park; Visiting Phu Quoc prison, Nguyen Trung Truc, Dinh Cau temples.

Resort tourism,

Combining of conferences, seminars or medical care.

Community tourism:

Discovering fishing villages of Ham Ninh, Rach Vem.

Agricultural tourism:

Visiting pepper gardens, honey farms, high-tech fruit and vegetable farms. Industrial tourism:

Sim wine production facility, fish sauce fermentation house.

Figure 4. Tourism value chain for Phu-Quoc

\subsubsection{Tourism Sustainable Connections Model}

In the case of Phu Quoc, three groups of connection between tourism and the three other economic sectors were analyzed. They are:

Tourism - Agriculture: Currently, hundreds of families have participated in the opening of sightseeing tours at pepper gardens and selling home products. Visiting tours at the floating fish, snail, and crab farms become more common in Ham Ninh commune, eco-garden tour at beekeeping farm in Duong To commune (Figure 5b). Fishing experience tour (Figure 5a) is one of the most unique tours in Phu Quoc. 
Tourism - Industry: Phu Quoc has many traditional craft villages that have been standardized and become industrial tourist destinations such as: Tours to sim wine production facilities (Figure 5d); Fish sauce fermentation house in Duong Dong and An Thoi towns (Figure 5c).

Tourism - Trade and Services: Trade and Services act as a bridge, making tourism resources from potential forms into commercial products, bringing them to consumers. In addition to professional trading partners such as tour operators, transportation services, residents, who own, create, and maintain tourism resources, may engage themselves in trade and services. Forms of participation include local tour guides; Board, bike, motorbike rental; Product showrooms, kiosks, street market; And providing accommodation as homestays for tourists.
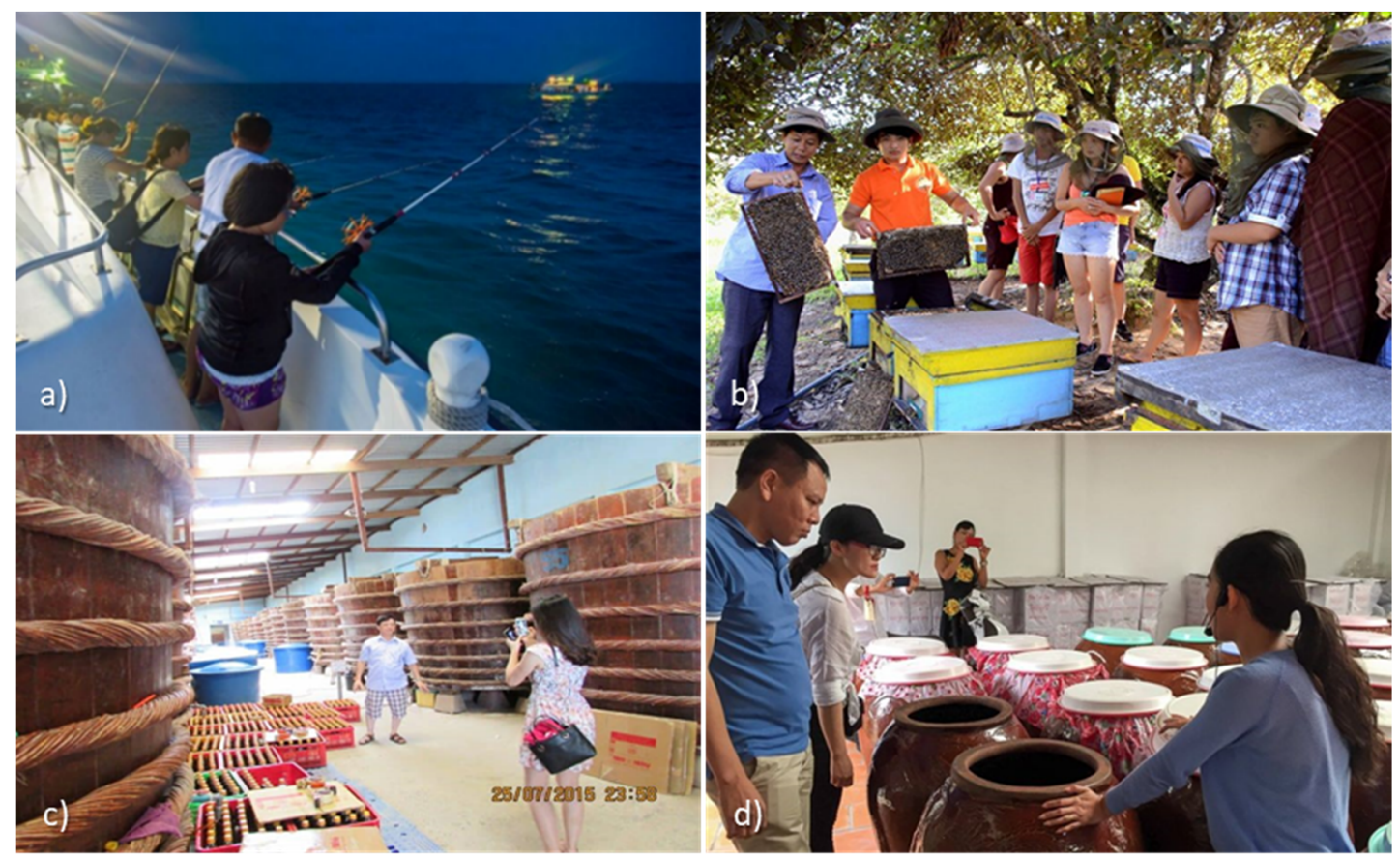

Figure 5. Tourist-Agriculture (uppers) and Tourism- Industrial (lowers) products in Phu Quoc Island

\subsubsection{Renewable Energy Development Model}

Renewable energy development is within the strategic orientation to 2030 of Phu Quoc. The long-standing reality is that the electrical power system, from production, transmission to distribution infrastructure, is largely stateowned and invested. The Prime Minister (2016) has issued a document on national electricity development planning. It clearly states that the electricity transmission network is under state ownership. This aims to ensure national energy security while encouraging private investors to invest in power production infrastructure and retail distribution. Particularly, priority is given to renewable energies such as wind, biogas, wave, solar power, and others.

In the case of Phu Quoc, the rising energy demand requires speeding up the investment process for new energy sources. At the present stage, private or public-private investments in wind and solar power generation are considered feasible. However, Phu Quoc needs effective management tools.

Figure 6 describes the model of energy production and coordination which promotes the development and sustainable use of energy in Phu Quoc Island. In the present, the Government, with four policy tools, is expected to play a key role in creating room for the investments on renewable energies. These include financial policy tools such as 1) Loan incentives, Budget support; 2) Tax and fee incentives; Along with regulatory policy tools such as 3) Control production and consumption through Restricted pricing (for non-renewable energy); And 4) Protected pricing in investment, production, and consumption of renewable energy, to ensure product costs remain at a level that is accessible to a large number of customers. 


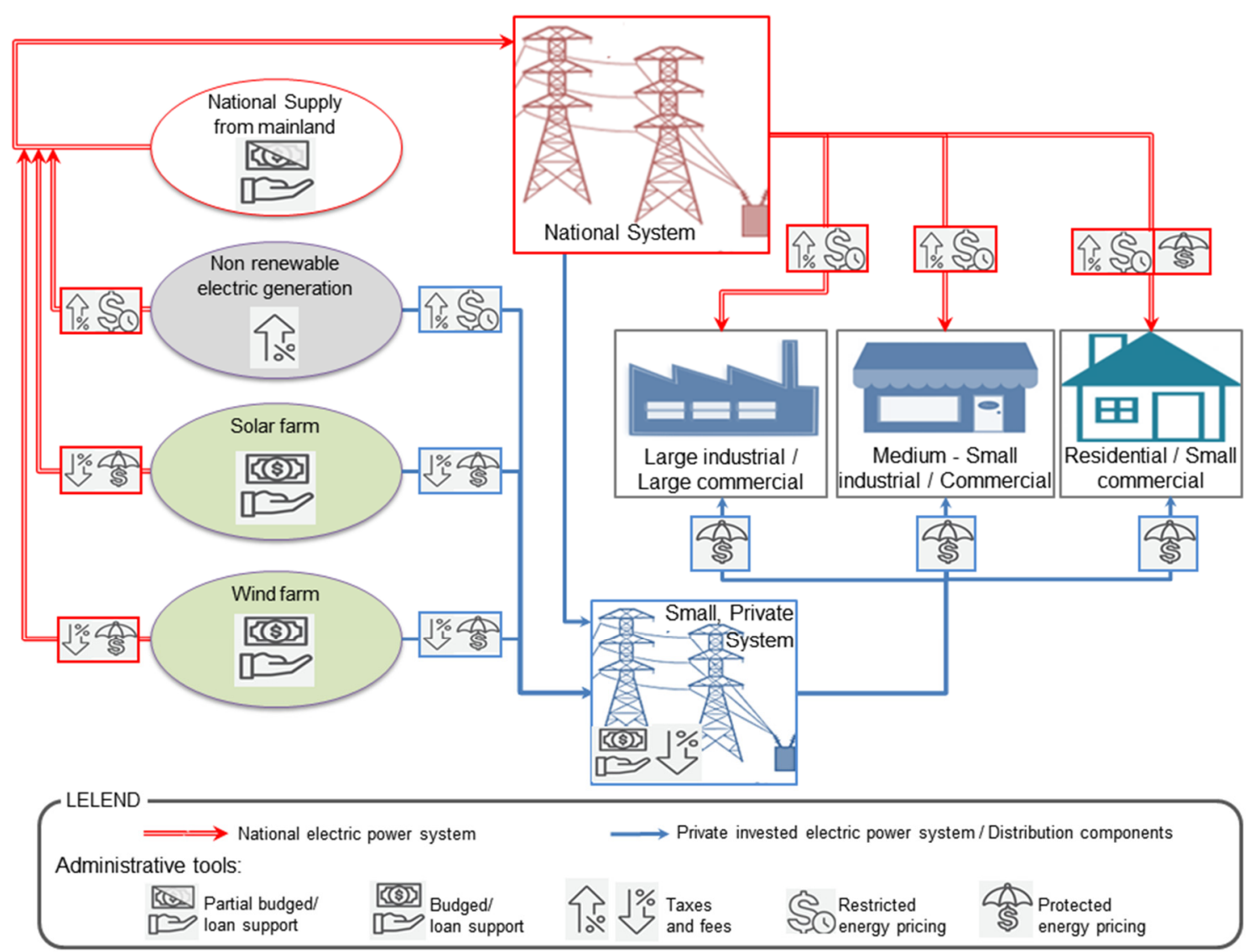

Figure 6. Model of energy development for Phu Quoc with priority to renewable energy

\subsubsection{Aqua-Agroforestry Model}

The "Capacity Building for Implementation of National Climate Change Strategy Project (CBICS)", organized by the UNDP (2014) has deployed a number of agroforestry models that are believed to have high economic values in Phu Quoc such as planting sim (Rose Myrtle) forests in combination with afforestation, fruit trees with beekeeping. To a practical implementation, this section proposes a model of different cultivation scenarios with Agriculture - Forestation - Aquaculture combination. The Table 1 presents six combinations that are feasible for different communities in Phu Quoc. It generalizes the roles of the four key partners. In which, the local community plays as the implementing partner while suggesting selective supports from the three others. 
Table 1. Agriculture-Forestation-Aquaculture combinations implemented by local community in Phu Quoc

\begin{tabular}{|c|c|c|c|}
\hline \multirow{2}{*}{ No. - } & Implemented by local community & \multirow{2}{*}{$\begin{array}{l}\text { Location of participation } \\
\qquad \text { (commune) }\end{array}$} & \multirow{2}{*}{$\begin{array}{l}\text { Suggested supports from the three } \\
\text { other key partners } \\
\text { (Government; Enterprises; and } \\
\text { Scientific Experts) }\end{array}$} \\
\hline & Combinations & & \\
\hline 1 & $\begin{array}{l}\text { Forest (silviculture) }+ \text { Fruit }+\begin{array}{l}\text { Mango, } \\
\text { Longan, } \text { Orange, }\end{array} \text { Tangerine, } \\
\text { Bee farm } \\
\text { Custard apple, Native bee. }\end{array}$ & $\begin{array}{l}\text { NW. Cua Can; Central Cua } \\
\text { Duong, W. Ham Ninh }\end{array}$ & $\begin{array}{l}\text { Cultivation Assistance: } \\
\text { - } \quad \text { Seedlings, breeds, } \\
\text { - Capital, }\end{array}$ \\
\hline 2 & $\begin{array}{l}\text { Forest (forestry trees) }+{ } \text { Ginger, Ginseng, Optional fruit tree } \\
\text { Medicinal plants }+ \text { fruit trees }\end{array}$ & $\begin{array}{l}\text { Cua Can; S., SW. Ham Ninh; } \\
\text { SE. Bai Thom }\end{array}$ & $\begin{array}{ll}\text { - } & \text { Supplies, } \\
\text { - } & \text { Technology and Technical }\end{array}$ \\
\hline 3 & $\begin{array}{l}\text { Melaleuca forest }+ \text { Pepper }+ \text { Melaleuca, Pepper, Catfish, Black } \\
\text { Brackish and freshwater fish Tiger Shrimp }\end{array}$ & $\begin{array}{l}\text { Cua Can; Cua Duong; NW. Bai } \\
\text { Thom; NE. Ganh Dau }\end{array}$ & $\begin{array}{l}\text { training, } \\
\text { - Sightseeing, Seminars. }\end{array}$ \\
\hline 4 & $\begin{array}{ll}\text { Mangroves }+ \text { Brackish and } \begin{array}{l}\text { Black Tiger shrimp, Cobia, } \\
\text { saltwater aquatic products }\end{array} & \begin{array}{l}\text { Grouper, Plaice, Red snapper, } \\
\text { Pompano, Mollusk, and Pearl. }\end{array}\end{array}$ & $\begin{array}{l}\text { NE., NW. Bai Thom; SE. Ganh } \\
\text { Dau; Cua Can }\end{array}$ & $\begin{array}{l}\text { Product Support: } \\
\text { - } \quad \text { Processing, } \\
\text { - } \quad \text { Preservation, }\end{array}$ \\
\hline 5 & $\begin{array}{l}\text { Forest (forestry trees) }+ \text { Fruit } \\
\text { trees }+ \text { Vegetables }+ \text { Cattle and } \text { Optional fruit tree Vegetables, } \\
\text { Poultry } \\
\text { Chicken, Cow, and Pig. }\end{array}$ & $\begin{array}{l}\text { W. Bai Thom; NE. and Central } \\
\text { Cua Duong; E. Duong To; W. } \\
\text { Ham Ninh }\end{array}$ & $\begin{array}{l}\text { - } \quad \text { Offtake, } \\
\text { - } \\
\text { - } \\
\text { - Tdvertise, } \\
\text { Trademark registration, }\end{array}$ \\
\hline 6 & $\begin{array}{l}\text { Forest (forestry trees) }+ \text { Wild Optional fruit tree, Wild Sim fruit } \\
\text { fruits + Fruit trees } \\
\text { (rose myrtle). }\end{array}$ & $\begin{array}{l}\text { E., SE. Cua Duong; W. Ham } \\
\text { Ninh; SW. Bai Thom; SW. } \\
\text { Ganh Dau }\end{array}$ & $\begin{array}{l}\text { Geographical indications. } \\
\text { Value Added Support: } \\
\text { - } \quad \text { Design travel tours, } \\
\text { - } \text { Design picnic + education } \\
\text { tours for students at all } \\
\text { levels, } \\
\text { - } \quad \text { Skills training to serve } \\
\text { tourists, } \\
\text { - } \quad \text { Traffic, } \\
\text { - Security, } \\
\text { - } \text { Food safety. }\end{array}$ \\
\hline
\end{tabular}

\subsection{Environmental SD Models, Toward Climate Change Adaptation}

\subsubsection{Benefit Balancing Model and the Sustainable Balance}

Figure 8 proposes a model to estimate the balance between forest protection and the community's livelihood in the context of climate change adaptation. In other words, this can be called as Benefit balancing model. The Forest changes and the Community changes are set as two opposing weighting objects. They represent the entire possible changes (understood as variation of weight of every individual) that occur at each side, possibly causing an imbalance. Climate change is considered to be the third factor. It directly affects the mass stability for both sides and on the entire system.

The balancing system is formed by an axe of Balancing bar and a ruler of Benefit gaining. While the first is constituted by efforts to conserve forests, protect the environment, and adapt to climate change, the second housing the variation of the Weights and acts as a regulatory ruler of Benefits thresholds of both sides. Weights present the type and quantity of the positive outputs for livelihood from efforts to protect the environment and to adapt to climate change.

While the system is always subject to change by both natural and human, Climate change adds challenges to efforts to make up the balance. Reinforced Balancing bar to keep the system rigid, together with adjustment of the Benefit gaining level of the Weights, in the objective, scope, scale, and even in vision, are expected to be the keys helping 
(Figure 8).

In Phu Quoc's case, three main groups of the positive outputs (Weights) for each side were clarified (Figure 8). In fact, people tend to push the benefits of both sides to the greatest extent possible. This does not guarantee a balance in the context of the volatility of three factors Nature, People, and Climate change. However, it is possible to do that when starting the balancing consideration. Next, base on each scenario of the benefit threshold to control the type and quantity of the outputs. Or conversely, predict the scenario of outputs (in types and number) to adjust their benefit thresholds.

It is important to note that even if the benefits have somehow achieved a "perfect" balance, the durability of the balancing bar will determine the ability of the system to maintain the load and the state of equilibrium. In other words, while technical adjustments could bring the Balance, durability and cohesion between efforts to protect the environment and climate change adaptation will ensure the Sustainability. Together, they create a Sustainable Balance.

\subsubsection{Climate Change and Sea Level Rise Adaptation Model.}

It is necessary to have an overall consideration and a comprehensive model, meeting the needs of preventation, mitigation and adaptation at the present and in the future, to toward SD of Phu Quoc, coping with challenges and extreme scenarios.

Actively living with climate change, sea level rise to take advantage of all the possible benefits it brings is considered as a comprehensive and radical solution against climate change in an active position. From the model of living with climate change of people in the Mekong delta by Le A. T. (2009), this section proposes a model for Phu Quoc as shown in Figure 9.

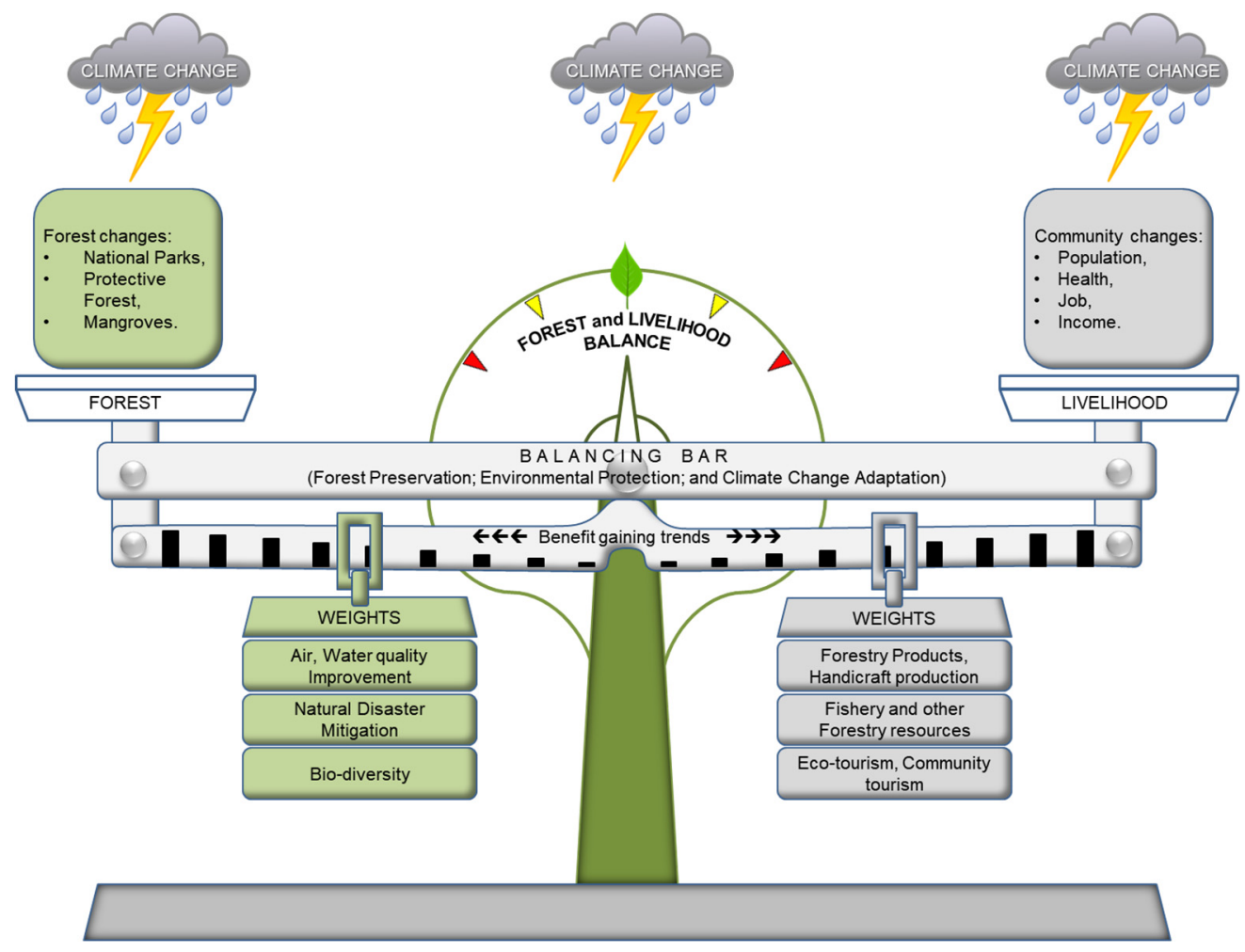

Figure 8. Benefit balancing between forest protection and livelihoods maintainence within the context of living with climate change 


\section{Living with climate change, sea level rise for Phu Quoc SEZ}

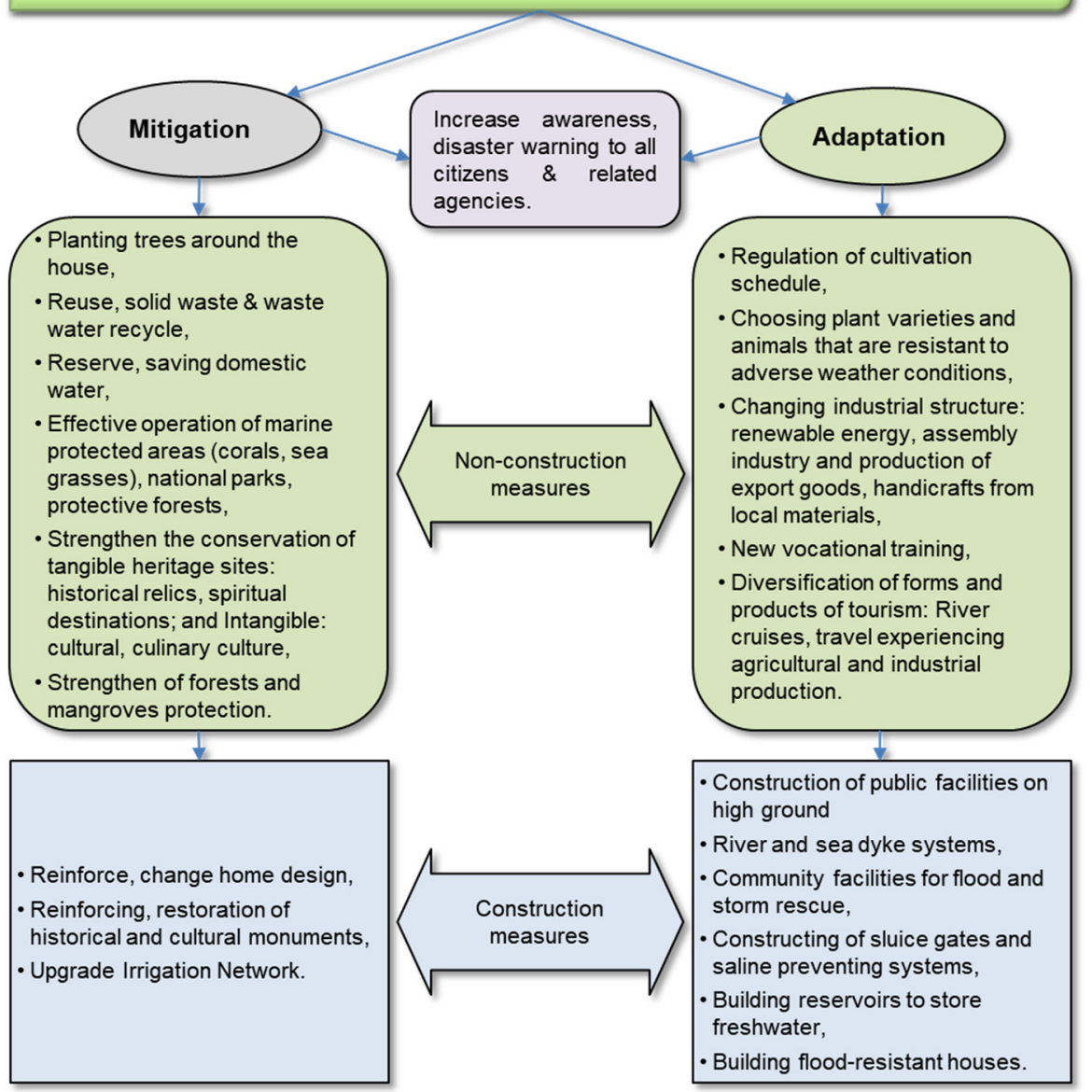

Figure 9. Model of living with climate change and sea level rise in Phu Quoc

Source: after Le A. T., 2009

\subsection{Social SD Policies and Policy Actions}

Sustainable social development focuses on balance, society needs to create favorable conditions for human development, enable everyone to develop their potential, and have an acceptable living condition. The social security system of Vietnam is built on the principles of risk management while promoting the role of providing basic social services for people. In the study area, the orientation and political commitments on social development policies have been widely mentioned. However, it is now necessary to bring them into practice.

In the study area, there are four basic groups of social policies that need to be considered. They include Risk Insurance policy, Sustainable Income policy, Social Assistance policy, and Basic Social Services policy. The analyses of existing issues and the proposing specific Policy actions for each group are discussed.

\subsubsection{Risk Insurance Policy}

Risk insurances, in which the Social Insurance (SI) system plays an important role in the life of each individual in the community. The most currently urgent issue, not only in Phu Quoc, is the need to ensure the right to access and accessibility to SI of each citizen.

Currently, there are some shortcomings and needs to change. They are: - The payment of SI premiums for employees is mandatory for employers. However, not all employers take it seriously. Tightening the legal system is necessary. - There are still questions about the responsibility of small and very small businesses to cover insurance premiums for workers. The legal system needs detail and clarity, along with a flexible corporate tax policy to encourage small employers to enforce workers' SI rights. - Participating in insurance for the group of self-employed workers, accordingy, is still voluntary. This group, however, is mostly of the low-income peoples 
in the community. Conversion of policies is suggested. For example, voluntary SI can change to semi-voluntary or compulsory, based on personal income tax control (for moderate-income earners), combined with welfare adjustment to support partial premium payment (for low-income or unemployed). Adjusting of policies to be able to create "minimum insurance packages" for workers might also be feasible in this case. Payment mechanisms, procedures, compensation value, as well as transparency in insurance payment are also issues that need to be improved to increase the effectiveness of social insurance as well as stimulate the access needs of the community.

\subsubsection{Sustainable Income Policy}

It contains policies on employment, ensuring minimum income, and poverty reduction, supporting people to actively prevent risks through the participation of the labor market and achieve sustainable minimum incomes. It is necessary to mobilize the participation of components such as: $\bullet$ Enterprises: In expanding job market, vocational training. $\cdot$ Credit funds, commercial banks, social banks, social organizations, professional associations: Through forms such as unsecured loans, encouraging self-employment by organizing, for example, cow bank, goat bank, seeds fund, fertilizer and post-harvest agricultural product exchange, and farm machinery sharing.

\subsubsection{Social Assistance Policy}

In addition to the state's regular social assistance policy, which is inherently limited, emergency assistance in the event of overcoming risks, beyond the control such as crop failure, natural disasters, epidemics, should be expanded through mobilizing philanthropists, encourage the expansion of the size and supporting form of charitable funds and community volunteer groups.

\subsubsection{Basic Social Service Policy}

Basic Social Service ensures people have access to basic services at a minimum, including Education, Health, Clean Water \& Environmental sanitation, Culture-Information-Communication. However, the implementation of these services, though minimal, still needs to be considered in the overall strategy of SD and living with climate change. $\bullet$ Regarding Education: For students, support through study promotion funds, school health care, combined with teaching on environmental protection, training in self-protection skills to deal with natural disasters and epidemics. For teachers, improving their lives through wage and allowance policies. For infrastructure, upgrading classrooms in the direction of safely coping with natural disasters such as storms and floods. $\bullet$ Regarding Health: Strengthening the community health system and public awareness is the key to prevent diseases. It then helps to reduce pressure on the health care system as well as the welfare system. - Culture-Information-Communication: Keeping people to have the rights to access information and communication and doing their culture is a basis. This is also an important channel that helps to raise public awareness about protecting traditional heritage and up-todate new knowledge. $\bullet$ Clean water: Ensuring equal access and safe use, sense of people to save water and protect a clean living environment.

\section{Conclusion}

Translating theoretical concepts, criteria for SD, interpreting them, and putting them into practical applications is always a great challenge. This study approached a simplified and visualized procedure to create an SD model. It helps the government, experts, partners, and even local people to better understand the structure, organization, and their roles in the implementation of the SD strategy. Although it may be necessary to have further adjustments, that method and procedure of building an SD structure can be applied to many other areas, by local managers and their partners.

The identification and analysis of the challenges, position, role, and the interactions between components of the SD helps affirm that while only the SDGs are relatively homogeneous in different study areas, implementing partners may have similarities, so the identification of challenges, priorities, determination of tasks and responsibilities in interactions between partners is highly variable. The SD model for each specific area always requires systematic analysis. It must be based on Practical conditions and pursuing Feasibility.

The overall structure, together with the solutions and detailed models established are the direct results, providing practical tools for implementing SD activities in Phu Quoc. However, the approach of the work and structure of the models allow flexible application for other study areas.

The policy actions discussed in the social SD models are experiences drawn from local practice, with successful lessons learned in regions across the country as well as from other countries in the world. They have initially demonstrated the effectiveness in reducing poverty, allowing people to participate more actively in the sustainable development strategy. 


\section{Acknowledgements}

The authors would like to express the best thanks to the colleagues at the Institute of Natural Resources, Environment, and Sustainable Development, to experts of the Vietnam Marine Geological Association for their comments. Our appreciation goes to the people and the administration of Phu Quoc Island for their kind help during the fieldwork. We would like to express our deep gratitude to the Vietnamese Ministry of Science and Technology for sponsoring the research project KC09-27 / 16-20 (MOST, 2020), making this work become possible.

\section{References}

Adhikari, O. (2018, August 15). Sustainable Development and its Challenges in Developing Countries. International Young Naturefriends IYNF. Retrieved March 24, 2020, from http://www.iynf.org/2018/08/aguide-to-sustainable-development-and-its-challenges-in-developing-countries/

Antle, J. M., \& Ray, S. (2020). Challenges of Sustainable Agriculture in Developing Countries. Sustainable Agricultural Development. Palgrave Studies in Agricultural Economics and Food Policy. Palgrave Macmillan, Cham. 95-138. https://doi.org/10.1007/978-3-030-34599-0_4

Dao, M. T., \& Pham, V. T. (2007). The project "Investigation and Assessment of the Current State of Phu Quoc Island Environment from 0m to 20m", Under The Overall Project "Building Measures to Protect Phu Quoc Island Environment to 2010 and Orientations to 2020". Project report. Archives, Ministry of Natural Resources and Environment, Hanoi.

Dow Jones. (2012). Guide to the Dow Jones Sustainability World Index, Version 12.0, 30 August 2012. S\&P Dow Jones Indices. Retrieved from https://www.resolve.ngo/docs/djsi-world-guidebook_tcm1071-337244.pdf

Du, V. T. (2013). Renewable Energy at Sea and Development Orientation In Vietnam. Archives, Research Institute of Sea and Islands. Hanoi.

GRI. (2002). Sustainability Reporting Guidelines. Global Reporting Initiative. Retrieved from https://studylib.net/doc-/8815537/gri-sustainability-reporting-guidelines-2002

IUCN. (1980). World Conservation Strategy - Living Resource Conservation for Sustainable Development. International Union for Conservation of Nature and Natural Resources 77p. Retrieved from https://portals.iucn.org/library/-efiles/documents/WCS-004.pdf

Kien Giang. (2018). Kien Giang Statistical Year Book, Statistical Publishing House, 582p. Retrieved from http://www.thuvienthongke.com/nien-giam-thong-ke-tinh-kien-giang-2018/v6358.aspx

Kopnina, H. (2016). The Victims of Unsustainability: a Challenge to Sustainable Development Goals, International Journal of Sustainable Development \& World Ecology, 23(2), 113-121. https://doi.org/10.1080/13504509.2015-.1111269

Kurniawan, R., \& Managi, S. (2018). Economic Growth and Sustainable Development in Indonesia: an Assessment. Bulletin of Indonesian Economic Studies. $54 . \quad 1-31$. https://doi.org/10.1080/00074918.2018.1450962

Le, A. T. (2009). Impact of Climate Change on Ecosystems and Rural Development in The Mekong Delta. Archives, Research Institute for Climate Change - Can Tho University. Retrieved from https://dragon.ctu.edu.vn/t/x.html

Le, T. K. T. (2016). Some Solutions for Sustainable Development of Vietnam's Island Economy in the Context of Climate Change. Vietnam Journal of Marine Science and Technology, 16(1), 12-20. Retrieved from http://www.vjs.ac.vn/index.php/jmst/article/viewFile/6426/6828

Minh, D. (2018, Jun 04). Special Economic Zone - Things to Know and Successful Models in The World. Sports and Culture Electronic Newspaper. Retrieved from https://thethaovanhoa.vn/xa-hoi/dac-khu-kinh-te-nhungdieu-can-biet-va-nhung-mo-hinh-thanh-cong-tren-the-gioi-n20180604112505138.htm

Minh, H. (2019, April 9). Environmentally friendly '4-in-1' waste disposal model. Environmental \& Life Electronic Newspaper. Retrieved from https://moitruong.net.vn/mo-hinh-xu-ly-rac-4-trong-1-than-thien-voi-moitruong/

MOST. (2020). Project KC09-27/16-20, Scientific Basis and Solutions for Sustainable Development of Coastal Economic Zones in Vietnam. Projects Category, Ministry of Science and Technology (MOST). Retrieved from http://kc09.vpct.gov.vn/ProjectSearch.html 
MPI. (2019). Circulars No. 03/2019/TT-BKHĐ: Regulation on Vietnam's Standard Development Statistics Indicators. Legal Document, Ministry of Planning and Investment, Vietnam. Retrieved from https://thuvienphapluat.vn/van-ban/bo-may-hanh-chinh/thong-tu-03-2019-tt-bkhdt-quy-dinh-bo-chi-tieuthong-ke-phat-trien-ben-vung-cua-viet-nam-406435.aspx

Ngo, V. L. (2013). Social Security \& Sustainable Development. Thu Dau Mot University Journal of Science (EJS), 4(11), 2-13. Retrieved from https://ejs.tdmu.edu.vn/.

Nguyen, H. S. (2009). Sustainable Economic Development In Vietnam (Unpublished doctoral thesis in Political Economy). University of Economics and Business - Vietnam National University (VNU-UEB). Hanoi, Vietnam.

Nitivattananon, V., \& Srinonil, S. (2019). Enhancing Coastal Areas Governance for Sustainable Tourism in the Context of Urbanization and Climate Change in Eastern Thailand. Advances in Climate Change Research, 10(1), 47-58. https://doi.org/10.1016/j.accre.2019.03.003

O'Connor, M. (2006). The "Four Spheres" Framework for Sustainability. Ecological Complexity, 3(4), 285-292. https://doi.org/10.1016/j.ecocom.2007.02.002

OECD/UNWTO/WTO. (2013). Aid for Trade and Value Chains in Tourism. Retrieved from https://www-.wto.org/english/tratop_e/devel_e/a4t_e/global_review13prog_e/tourism_28june.pdf

Pham, H. H. (2006). Project Report on: Integrated Assessment of Natural-Socio-Economic Potentials, Establishing Scientific Bases and Sustainable Development Solutions for Some Island Districts. Project KC-0920 / 01-05. Archive, Ministry of Science and Technology, Hanoi, Vietnam. 485p.

Pham, V. T., \& Dao, M. T. (2018). Project Explanation: Scientific Basis and Solutions for Sustainable Development of Coastal Economic Zones in Vietnam. Archive, Institute of Natural Resources, Environment and Sustainable Development. Hanoi, Vietnam, 144p.

Phu Quoc. (2020, July 22). Phu Quoc Island. In Wikipedia, the free encyclopedia. Retrieved January 22, 2020, from https://en.wikipedia.org/wiki/Ph\%C3\%BA_-Qu\%E1\%BB\%91c

Rabe, N., Osman, M., \& Bachok, S. (2012). Towards Sustainable Regional Economic Development -The case study of Iskandar Malaysia. Conference: 2012 EAROPH World Congress, At Daegu, Korea. Retrieved from https://www.researchgate.net/publication/275215209_Towards_Sustainable_Regional_Economic_Develop ment_The_case_study_of_Iskandar_Malaysia.

Stephen, P., Catherine, L. K., Simon, A. L., Stephen, R. C., Gretchen, C. D., Paul, R. E., Geoffrey, M. H., \& Jane, L. (2019). Role of Economics in Analyzing the Environment and Sustainable Development. Proceedings of the National Academy of Sciences Mar 2019, 116(12), 5233-5238. https://doi.org/10.1073/pnas.1901616116

The Prime Minister. (2004). Approval on "Project on Overall Development of Phu Quoc Island, Kien Giang province up to 2010 and a vision toward 2020". Decision 178/2004 / Qd-Ttg of The Prime Minister. Retrieved from http://vbpl.vn/botuphap/Pages/vbpq-toanvan.aspx?ItemID=19135

The Prime Minister. (2013). Decision On the Establishment of Phu Quoc Economic Zone, Kien Giang province. Decision 31/2013/QD-TTg of The Prime Minister. Retrieved from https://thuvienphapluat.vn/vanban/Doanh-nghiep/Quyet-dinh-31-2013-QD-TTg-thanh-lap-Khu-kinh-te-Phu-Quoc-tinh-Kien-Giang189252.aspx.

The Prime Minister. (2016). Approval Decision on Adjustment of National's Electric Power Development Plan, Period 2011-2020, With Consideration to Year 2030. Decision 428/QD-TTg of The Prime Minister. Retrieved from https://thuvienphap-luat.vn/van-ban/thuong-mai/Quyet-dinh-428-QD-TTg-de-an-dieu-chinh-quyhoach-phat-trien-dien-luc-quoc-gia-2011-2020-2030-2016-306608.aspx

Tosun, C. (2001). Challenges of Sustainable Tourism Development in the Developing World: The Case of Turkey. Tourism Management, 22, 289-303. https://doi.org/10.1016/S0261-5177(00)00060-1

Ugochukwu, B. (2019). Partnerships for Sustainable Development: Analyzing the Challenges. New Thinking on SDGs and International Law Policy Brief 1 - March 2019. Centre for International Governance Innovation. Retrieved from https://www.cigionline.org/publications/partnerships-sustainable-development-analyzingchallenges.

UN. (2013). World Economic and Social Survey 2013: Sustainable Development Challenges. Department of Economic and Social Affairs. United Nations publication, E.13.II.C.1, 216p. Retrieved from https://sustainabledevelopment-.un.org/content/documents/2843WESS2013.pdf 
UN. (2015). Transforming Our World: The 2030 Agenda for Sustainable Development. United Nation A/RES/70/1. Retrieved from https://sustainabledevelopment.un.org/content/documents/_21252030\%20Agenda\%20for\%20Sustainable\%20Development\%20web.pdf

UNCTAD. (2019). World Investment Report 2019. Chapter IV Special Economic Zones. Retrieved from https://unctad.org/en/PublicationChapters/WIR2019_CH4.pdf

UNDP. (2014). Capacity Building for Implementaion of National Climate Change Strategy Project (CBICS). Project on environment, climate change \& disasters. Retrieved May 18, 2019, from https://www.vn.undp.org/content/vietnam/en/home/operations/projects/environment_climatechange/cbics.html

\section{Copyrights}

Copyright for this article is retained by the author(s), with first publication rights granted to the journal.

This is an open-access article distributed under the terms and conditions of the Creative Commons Attribution license (http://creativecommons.org/licenses/by/4.0/). 